\title{
EFFECT OF SOME ABIOTIC FACTORS ON THE POPULATION FLUCTUATION OF SOME PESTS INFESTING OKRA PLANTS, WITH THE USING OF SOME COMPOUNDS IN THEIR CONTROLLING

\author{
Abdel Hamed, Neama A. ${ }^{1}$; H. S. Shaalan ${ }^{2}$; Samia A. Yasin ${ }^{2}$ \\ and Aziza M. M. Abou-Zaid ${ }^{2}$ \\ 1- Zoology Dept., Faculty of Science (Girls), Al-Azhar University, \\ 2- Plant Protection Research Institute, (ARC). Dokki, Giza.Egypt.
}

\begin{abstract}
Field experiments were conducted at Qalyubiya Governorate during two successive seasons 2009 and 2010 to study the population fluctuation of some sapsucking pests, Bemisia tabaci (Genn), Thrips tabaci, Liriomyza trifolii (Burgess) and Tetranychus urtica Koch on Okra plants, and controlling them by using of Azadirachtin (Neemazal 5\% EC), the natural oil (Clove oil, 5\% EC), Plant extract Damaseia 1\% DC and Vertimec $1.8 \%$ EC. Also the effect of these compounds and pests on chlorophyll of the leaves during the two successive seasons. The mean number of $B$. tabaci firstly occurred on May $11^{\text {th }}$ and increased gradually to reach the peak at August $31^{\text {st }}$ during 2009 season. While the infestation rates of T. tabaci, L. trifolii and T. urtica increased gradually and reached its peak in $14^{\text {th }}, 3^{\text {rd }}$ and $10^{\text {th }}$ August in 2009 season, respectively. The weather factors (maximum, minimum, mean temperature) and plant age had significant positive effect on population of $B$. tabaci, T. tabaci, L. trifolii and $T$. urtica while the relative humidity had negative significant effect on population of $B$. tabaci, T. tabaci, L. trifolii and T. urticae during the two studied seasons 2009 and 2010. The percentage of explained variance of the four tested factors during the two seasons were $91.50 ; 94.60 \%$ for B. tabaci, $88.10 ; 89.90 \%$ in case of T. tabaci, 73.40 $69.20 \%$ on L. trifolii and 82.10 and $84.70 \%$ for T. urticae during the two seasons, respectively. The bioactivity of the four pesticides, the obtained results showed that Cloves oil, Damaseia and Neemazal seam to be closely similar in the order of mean reduction percentages of $T$. tabaci, $L$. trifolii and $T$. urticae $(59.53,59.33 \& 60.30)$, (54.00, 55.90\&55.10) and (76.20, 77.60\&85.40, respectively) during the season 2009. On the other hand, Cloves oil caused 82.14 and 82.65 mortality of eggs and nymphal stages of whitefly followed by Damaseia (83.08\&81.98) and Neemazal (75.50\&73.30) during the two seasons. During 2009 season, the highest content of chlorophyll $A$ in treated the okra leaves were obtained with using Cloves oil, Vertimec and Plant Extract Damaseia in which the leaves had significantly more chlorophyll content than in control. During 2010 seasons, the leaves sprayed with Cloves oil had the highest amount of chlorophyll content, while plants sprayed with Vertimec showed significantly lower chlorophyll content than in the control plants.
\end{abstract}

\section{INTRODUCTION}

Okra plants are liable to infestation by many phytophagous pests which the Sap-sucking ones such as the tomato whitefly Bemisia tabaci (Genn.), onion thrips Thrips tabaci (Lind), the red spider mite Tetranychus urticae Koch and Liriomyza trifolii (Burgess), they are considered the most common and important insect pests. In cases of heavy infestation, these pests cause serious damage to plants, leading to great reduction in the final yield (Basma, et al., 2006). The cultivated area of okra estimated at 11526 
feddans which produced about 66922 tons with an average of 6.0 tons /feddan, (Eid, 1985).

The whitefly, Bemisia tabaci, the two-spotted spider mite T. urticae were considered the main pests infesting okra plants during the plantation, and causes losses not only in quantity but also in quality of the yield. They feed on the plant sap and cause leaf drop and also may prevent the fruit maturity. Whiteflies also produce sticky honeydew, which cause crop damage (Perkins, 1983) and (Lentern Van and Noldus, 1984). Also, T. urticae is one the most important pests which it feeds on the plant sap and causing serious damage varying according to the degree of infestation (Abou-Zaid, 2003 and Park and Lee, 2007).

In the recent years, the environmental preferences of different vegetable crop pests have gained a significant importance in pest control research programs. However, some studies were carried out with regard to the effect of climatic factors in the population dynamics of damage, losses as well as controlling pests infesting vegetable crops which studied by many authors, (kumar and Sharma 1993; Kappoor et al., 1997; El-Kawass, 2000 and Abou-Zaid 2003).

So, the present investigation was carried out to explain the changes in the population dynamics of some pests infesting okra plants, their relation with some weather factors and applying of some compounds against $T$. tabaci, B. tabaci, L. trifolii and T. urticae with reference to the yield.

\section{MATERIALS AND METHODS}

Population fluctuation of some sap-sucking pests infesting okra plants:

Experiments were carried out at the experimental farm of Kaha Research Station, Qalyubiya Governorate during the two successive seasons 2009 and 2010. An area of 1/4 feddan was sown of okra seeds (Abelmoschus esculentus. L), Eskandarani variety, on April $4^{\text {th }}$ during 2009 and 2010 seasons. The planting area was divided into three plots.

After 37 days of sowing date and during the growth period (19 weeks), leaves from each replicate were kept in tightly closed paper bags and transferred to the laboratory where the observed studied pests were counted by aid of stereomicroscope. The total individual (nymphs + adults) of $T$. tabaci, (egg + nymphal stages) of B. tabaci, larvae of L. trifolii and (egg + immature + adults) of $T$. urticae were estimated by counting the total numbers/leaf on the underside surface of leaves.

Sample of 10 leaves/plot were collected from the chosen okra plants at the morning for counting the adults of whitefly before they tend to be more active, (Gameel, 1973).

The records of meteorological data, the daily mean of minimum, maximum temperature and daily mean relative humidity, were obtained from the meteorological records of Central Laboratory for Agriculture Climate, Agriculture Research Center at Dokki, (preventative Shebien El-Qanater). The daily records of these factors were recalculated to get the daily averages within one week before the sampling date. 
Efficacy of some pesticides in reducing the population density of some sap-sucking pest on okra plants:

Field experiment was carried out throughout 2009 and 2010 seasons in Kaha Experimental Research Station, Qalyubiya Governorate. An area of about $525 \mathrm{~m}^{2}$ cultivated by okra seeds (var. Eskandarani) on April, $4^{\text {th }}$. The whole area was divided into 5 plots each of three replicates; all of them were arranged in a randomized complete block design.

Four compounds including; Azadirachtin 1500 ppm (Neemazal, 5\% EC), the natural oil (Clove oil, 5\% EC), Plant extract Damaseia 1\% DC (Ambrosia maritime) and Vertimec $1.8 \%$ EC were used to evaluate them against the individuals of $T$. tabaci (nymphs + adults), B. tabaci (egg + nymphal stages), L. trifolii (nymphs) and T. urticae (egg +immature stages+ adults) infesting okra plants, (Table, 1).

Table (1): The environmentally safe compounds which used against different pests infesting okra plants.

\begin{tabular}{|l|c|c|l|c|}
\hline $\begin{array}{c}\text { Trade } \\
\text { name }\end{array}$ & $\begin{array}{c}\text { Active } \\
\text { ingredient }\end{array}$ & Formulation & \multicolumn{1}{|c|}{ Scientific name } & $\begin{array}{c}\text { Concentration/ } \\
\text { 100 lit. of water }\end{array}$ \\
\hline Neemazal & $5 \%$ & EC & Azadirachta indica A., Fam: Meliaceae & 200 \\
\hline Cloves oil & $5 \%$ & EC & Syzyguim aromaticu & $250 \mathrm{ml}$ \\
\hline Damaseia & $1 \%$ & DC & Ambrosia maritime & $300 \mathrm{ml}$ \\
\hline Vertimec & $1.8 \%$ & EC & Abemectin & $40 \mathrm{ml}$ \\
\hline
\end{tabular}

DC = Dissoluble concentration

$\mathrm{EC}$ = Emulsifiable concentration

For the efficacy of the tested compounds against the above mentioned pests, fifteen samples of 10 leaves /plot were collected before spraying and after $1,3,7$, and 10 days.

Samples were transferred to the lab. and examined using stereomicroscope to recording the different stages of the pests.

Effects of applied treatments on chlorophyll content in okra leaves:

Leaf samples were taken after 1,5 and 10 days of treatments for determination of chlorophyll content which estimated as chlorophyll unit using chlorophyll Meter Spad-502 (El-Lakwah et al, 2003).

Statistical analysis:

The statistical analysis (ANOVA, Simple correlation and partial regression) of the obtained data were performed by using SAS program (SAS Institute, 1988). Also the difference between means was conducted by using Duncan's multiple range tests in this program. The reduction percentages in the number of pests were calculated by using equation of Henderson and Tilton (1955).

\section{RESULTES}

Population dynamics of some sap-sucking pests infesting okra plants:

Data tabulated in Tables, 1\&2 showed that, the rate of natural infestation of white fly B. Tabaci; T. tabaci; L. trifolii and T. urticae individuals to okra leaves during 2009 and 2010 seasons. 
The plants of okra were liable for infestation with $B$. tabaci individuals throughout the whole period of plant growth that extended from the first week of May with averages of 4.70 \&5.30 individuals/leaf during 2009 and 2010 seasons, respectively. The level of infestation increased gradually to reach its maximum ( $84.70 \& 91.80$ individuals/leaf) on August $31^{\text {st }}$. Then decreased to $79.80 \& 18.90$ individuals by September $14^{\text {th }}$, during the two studied seasons, respectively, Tables $1 \& 2$.

Table (2): Population fluctuation of some economic pests infesting okra plants with the corresponding climatic factors during the plantation season 2009, at Qalyubiya Governorate.

\begin{tabular}{|c|c|c|c|c|c|c|c|c|c|}
\hline \multirow[b]{2}{*}{$\begin{array}{c}\text { Inspections } \\
\text { date }\end{array}$} & \multirow{2}{*}{$\begin{array}{c}\text { Plant } \\
\text { age } \\
\text { (days) }\end{array}$} & \multicolumn{4}{|c|}{ Mean No. of pests/ leaf } & \multicolumn{4}{|c|}{ Climatic factors } \\
\hline & & $\begin{array}{c}B . \\
\text { tabaci }\end{array}$ & $\begin{array}{c}T . \\
\text { tabaci }\end{array}$ & $\begin{array}{c}L . \\
\text { trifolii }\end{array}$ & T. urtica & $\begin{array}{l}\text { Max. } \\
\text { Temp. }\end{array}$ & $\begin{array}{c}\text { Min. } \\
\text { Temp. }\end{array}$ & $\begin{array}{l}\text { Mean } \\
\text { Temp. }\end{array}$ & $\begin{array}{l}\text { Mean } \\
\text { RH\% }\end{array}$ \\
\hline May, $11^{\text {th }}$ & 37 & 4.70 & 0.00 & 0.00 & 4.30 & 38.86 & 21.29 & 30.07 & 25.29 \\
\hline $18^{\text {th }}$ & 44 & 7.90 & 0.00 & 0.00 & 6.50 & 38.57 & 19.71 & 29.14 & 30.36 \\
\hline $25^{\text {th }}$ & 51 & 13.00 & 0.00 & 0.00 & 5.70 & 46.29 & 23.43 & 34.86 & 24.50 \\
\hline June, $1^{\text {st }}$ & 58 & 15.60 & 4.00 & 0.60 & 8.60 & 44.00 & 25.40 & 34.70 & 23.20 \\
\hline $8^{\text {th }}$ & 65 & 19.30 & 1.00 & 0.40 & 10.60 & 35.06 & 22.80 & 28.93 & 63.79 \\
\hline $15^{\text {th }}$ & 72 & 25.00 & 2.60 & 1.00 & 13.40 & 36.41 & 23.93 & 30.17 & 60.43 \\
\hline $22^{\text {nd }}$ & 79 & 28.70 & 3.80 & 1.80 & 20.40 & 33.49 & 22.66 & 28.07 & 57.07 \\
\hline $29^{\text {th }}$ & 86 & 32.30 & 3.20 & 1.20 & 18.90 & 35.59 & 22.93 & 29.26 & 55.93 \\
\hline July, $6^{\text {th }}$ & 93 & 39.70 & 5.70 & 1.60 & 21.00 & 34.37 & 22.37 & 28.37 & 57.71 \\
\hline $13^{\text {th }}$ & 100 & 35.20 & 4.80 & 1.80 & 22.80 & 35.46 & 22.74 & 29.10 & 55.90 \\
\hline $20^{\text {th }}$ & 107 & 36.20 & 3.40 & 1.50 & 17.30 & 35.11 & 23.54 & 29.33 & 57.50 \\
\hline $27^{\text {th }}$ & 114 & 42.30 & 5.90 & 2.30 & 13.80 & 35.09 & 22.11 & 28.60 & 55.29 \\
\hline Aug., $3^{\text {rd }}$ & 121 & 38.40 & 7.60 & 2.80 & 25.70 & 34.64 & 21.89 & 28.26 & 57.36 \\
\hline $10^{\text {th }}$ & 128 & 45.10 & 9.30 & 1.70 & 28.10 & 35.69 & 23.80 & 29.74 & 56.07 \\
\hline $17^{\mathrm{th}}$ & 135 & 58.60 & 13.20 & 1.10 & 23.40 & 32.91 & 19.94 & 26.29 & 55.79 \\
\hline $24^{\text {th }}$ & 142 & 69.40 & 18.80 & 1.90 & 31.10 & 35.46 & 19.37 & 26.14 & 54.36 \\
\hline $31^{\mathrm{st}}$ & 149 & 84.70 & 16.30 & 1.20 & 28.60 & 34.80 & 21.80 & 28.63 & 53.21 \\
\hline Sept., $7^{\text {th }}$ & 156 & 83.20 & 21.20 & 1.30 & 25.90 & 29.77 & 21.40 & 28.10 & 53.14 \\
\hline $14^{\text {th }}$ & 163 & 79.80 & 20.30 & 0.80 & 29.30 & 27.97 & 20.20 & 24.03 & 53.43 \\
\hline Total & & 759.10 & 141.10 & 23.00 & 355.40 & & & & \\
\hline Mean士 S.E. & & $\begin{array}{c}39.95 \pm \\
5.72\end{array}$ & $\begin{array}{c}7.43 \pm \\
1.62\end{array}$ & $\begin{array}{c}1.21 \pm \\
0.18\end{array}$ & $\begin{array}{c}18.71 \pm \\
1.98\end{array}$ & & & & \\
\hline
\end{tabular}

The first appearance of $T$. tabaci per leaf was $4.0 \& 0.8$ individuals/leaf on Jun $1^{\text {st }}$, then increased gradually to reach its peak on September $7^{\text {th }}$ and August $24^{\text {th }}$ (21.20 \& 24.30 individuals/leaf), on both seasons 2009 and 2010 , respectively. After that, the population decreased to reach (20.30\& 5.80 individuals/leaf) at the end of the season, at the $2^{\text {nd }}$ week of September, during two seasons, respectively.

Infestation of the plants by $L$. trifolii started with an average $0.60 \& 0.40$ individuals/leaf at the end of May. Then, the population increased gradually to reach its peak ( $2.80 \& 2.30$ individuals /leaf) on August $3^{\text {rd }}$ and $24^{\text {th }}$, then decreased gradually by the time until the end of the growing seasons $(0.80$ $\& 1.60$ individuals/leaf), respectively.

Okra plants were infected with certain degree of T. urticae during 2009 seasons. As its first appearance occurred by an average 4.30 individuals/leaf on the $2^{\text {nd }}$ week of May, while in the subsequent season the mite appears on $15^{\text {th }}$ of June with an average 0.40 individuals/leaf. Then the population 
increased gradually to reach its peak on August $24^{\text {th }}$ and $10^{\text {th }}(31.10 \& 13.60$ individuals/leaf) and slightly decreased by the end of the season to be 29.30 \& 3.20 individuals/leaf for the two seasons, respectively (tables, 2\&3).

Statistically, there is a significant difference in the population of $T$. urticae between the two seasons, where, population increased gradually with plant age during the two seasons, then decreased gradually to reach the lowest rate at the end of inspections. This result indicated clearly that young fresh plants are more suitable for $T$. urticae.

In this regard, Jaydeb et al., (1999) determined the seasonal incidence of insect pests, yield loss, and to evaluate different okra varieties against insect pests and their management.

Table (3): Population fluctuation of some economic pests infesting okra plants with the corresponding climatic factors during the plantation season 2010, at Qalyubiya Governorate.

\begin{tabular}{|c|c|c|c|c|c|c|c|c|c|}
\hline \multirow[b]{2}{*}{$\begin{array}{l}\text { Inspections } \\
\text { date }\end{array}$} & \multirow{2}{*}{$\begin{array}{c}\text { Plant } \\
\text { age } \\
\text { (days) }\end{array}$} & \multicolumn{4}{|c|}{ Mean No. of pests/ leaf } & \multicolumn{4}{|c|}{ Climatic factors } \\
\hline & & $\begin{array}{c}B . \\
\text { tabaci }\end{array}$ & $\begin{array}{c}T . \\
\text { tabaci }\end{array}$ & $\begin{array}{c}L . \\
\text { trifolii }\end{array}$ & T. urtica & $\begin{array}{l}\text { Max. } \\
\text { Temp. }\end{array}$ & $\begin{array}{l}\text { Min. } \\
\text { Temp. }\end{array}$ & $\begin{array}{l}\text { Mean } \\
\text { Temp. }\end{array}$ & $\begin{array}{l}\text { Mean } \\
\text { RH\% }\end{array}$ \\
\hline May, $11^{\text {th }}$ & 37 & 5.30 & 0.00 & 0.00 & 0.00 & 17.00 & 31.00 & 24.00 & 44.00 \\
\hline $18^{\text {th }}$ & 44 & 6.10 & 0.00 & 0.00 & 0.00 & 18.00 & 30.00 & 24.00 & 49.00 \\
\hline $25^{\text {th }}$ & 51 & 15.30 & 0.00 & 0.40 & 0.00 & 17.00 & 30.00 & 23.50 & 45.00 \\
\hline June, $1^{\text {st }}$ & 58 & 18.60 & 0.80 & 0.50 & 0.00 & 18.00 & 29.00 & 23.50 & 48.00 \\
\hline $8^{\text {th }}$ & 65 & 21.80 & 1.90 & 0.80 & 0.00 & 18.00 & 31.00 & 24.50 & 50.00 \\
\hline $15^{\text {th }}$ & 72 & 25.60 & 3.20 & 0.90 & 0.40 & 20.00 & 32.00 & 26.00 & 46.00 \\
\hline $22^{\text {nd }}$ & 79 & 29.20 & 4.10 & 1.20 & 2.50 & 21.00 & 34.00 & 27.50 & 47.00 \\
\hline $29^{\text {th }}$ & 86 & 34.60 & 5.20 & 1.70 & 6.30 & 23.00 & 36.00 & 29.50 & 45.00 \\
\hline July, $6^{\text {th }}$ & 93 & 41.20 & 6.80 & 1.90 & 7.90 & 21.00 & 33.00 & 27.00 & 52.00 \\
\hline $13^{\text {th }}$ & 100 & 34.00 & 3.20 & 1.50 & 8.20 & 23.00 & 36.00 & 29.50 & 50.00 \\
\hline $20^{\text {th }}$ & 107 & 38.90 & 3.00 & 1.40 & 10.10 & 24.00 & 30.00 & 27.00 & 50.00 \\
\hline $27^{\text {th }}$ & 114 & 45.10 & 6.90 & 1.20 & 10.90 & 31.00 & 21.00 & 26.00 & 53.00 \\
\hline Aug., $3^{\text {rd }}$ & 121 & 39.90 & 8.20 & 1.00 & 11.80 & 33.00 & 20.00 & 26.50 & 55.00 \\
\hline $10^{\text {th }}$ & 128 & 48.20 & 11.10 & 1.10 & 13.60 & 32.00 & 20.00 & 26.00 & 53.00 \\
\hline $17^{\text {th }}$ & 135 & 71.60 & 19.80 & 1.50 & 9.70 & 31.00 & 21.00 & 26.00 & 51.00 \\
\hline $24^{\text {th }}$ & 142 & 84.90 & 24.30 & 2.30 & 9.20 & 30.00 & 18.00 & 24.00 & 54.00 \\
\hline $31^{\text {st }}$ & 149 & 91.80 & 9.20 & 2.00 & 5.10 & 30.00 & 18.00 & 24.00 & 52.00 \\
\hline Sept., $7^{\text {th }}$ & 156 & 30.20 & 7.50 & 1.90 & 7.80 & 31.00 & 21.00 & 26.00 & 50.00 \\
\hline $14^{\text {th }}$ & 163 & 18.90 & 5.80 & 1.60 & 3.20 & 25.00 & 21.00 & 23.00 & 50.00 \\
\hline Total & & 701.20 & 121.00 & 22.90 & 106.70 & & & & \\
\hline Mean士 S.E. & & $\begin{array}{c}36.91 \pm \\
5.49\end{array}$ & $\begin{array}{c}6.37 \pm \\
4.36\end{array}$ & $\begin{array}{l}1.21 \pm \\
4.36\end{array}$ & $\begin{array}{c}5.62 \pm \\
4.36\end{array}$ & & & & \\
\hline
\end{tabular}

The relation between some climatic factors and plant age on the population fluctuation of some sap-sucking pests infesting okra plants:

With regard to the effect of plant age on the occurrence of $B$. tabaci on okra, the simple correlation " $r$ " indicated significant positive correlation between the plant age and the insect $B$. tabaci population during the two seasons, $(r=0.961 \& 0.970)$ for $1^{\text {st }}$ and $2^{\text {nd }}$ seasons, respectively). The partial regression analysis for the effect of plant age on $B$. tabaci population revealed significant positive effect, (Table, 4). 
Table (4): Effect of plant age and certain climatic factors on the population fluctuation of $B$. tabaci on okra plants at Qalyubiya Governorate.

\begin{tabular}{|c|c|c|c|c|c|c|c|c|c|c|c|}
\hline \multirow{2}{*}{ 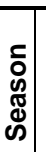 } & \multirow{2}{*}{ Factors } & \multicolumn{3}{|c|}{$\begin{array}{c}\text { Simple correlation } \\
\text { values }\end{array}$} & \multicolumn{4}{|c|}{ Partial regression values } & \multicolumn{2}{|c|}{$\begin{array}{c}\text { Analysis of } \\
\text { variance }\end{array}$} & \multirow{2}{*}{ E.V. \% } \\
\hline & & $\mathbf{r}$ & b & S.E. & b. reg. & S.E. & $\mathbf{T}$ & $\mathbf{P}$ & $\mathbf{F}$ & $\mathbf{P}$ & \\
\hline \multirow{4}{*}{ ¿ั่ } & Plant age & 0.961 & 0.183 & 0.033 & 9.60 & 0.148 & 5.64 & 0.01 & \multirow{4}{*}{39.85} & \multirow{4}{*}{0.01} & \multirow{4}{*}{91.5} \\
\hline & Mean max. temp. & 0.704 & 0.734 & 0.680 & 2.94 & 0.328 & 2.08 & 0.03 & & & \\
\hline & Mean min. temp. & 0.603 & 12.19 & 14.35 & 7.14 & 0.224 & 2.85 & 0.01 & & & \\
\hline & Mean RH\% & -0.794 & 0.758 & 0.134 & 6.75 & 0.115 & 3.566 & 0.07 & & & \\
\hline & Plant age & 0.970 & 0.99 & 0.274 & 10.16 & 0.207 & 4.18 & 0.01 & \multirow{4}{*}{63.62} & \multirow{4}{*}{0.01} & \multirow{4}{*}{94.6} \\
\hline 우 & Mean max. temp. & 0.627 & -0.113 & 0.836 & 2.15 & 0.108 & 0.136 & 0.03 & & & \\
\hline & Mean min. temp. & 0.624 & -0.189 & 0.676 & 3.33 & 0.213 & 0.28 & 0.03 & & & \\
\hline & Mean RH\% & -0.817 & 0.693 & 0.299 & 7.39 & 0.211 & 2.317 & 0.01 & & & \\
\hline
\end{tabular}

Statistical analysis of the simple correlation indicated significant positive correlation between $B$. tabaci population and the mean of maximum temperature $(r=0.704 \& 0.643)$ and also with the mean of minimum temperature $(r=0.603$ and 0.624$)$.

The amount of variability that could be attributed to the combined effect of the tested plant age, weather factors on $B$. tabaci population were 91.50 and $94.60 \%$ for the two seasons 2009 and 2010 , respectively.

These results are in the same direction of that obtained by Shalaby (2004) who found a significant correlation between weekly minimum temperature and the total of both adults and immature stages of $B$. tabaci population, while it was insignificant between weekly relative humidity and its population.

The simple correlation coefficient " $r$ " indicated insignificant positive correlation between the plant age and the insect $T$. tabaci population during the two seasons, $r=0.917$ and 0.936 during 2009 and 2010 seasons, respectively, (Table, 5$)$.

Significant positive correlations between both daily mean maximum and minimum temperature and T. tabaci population were observed; while, significant negative one was recorded with mean relative humidity.

The obtained results revealed that, significant effect for the combined effect of the tested plant age, weather factors on the insect activity during the two seasons, as the amount of variability, attributed to the combined effect of the three factors on T. tabaci population was 88.10 and $89.90 \%$ during 2009and 2010 seasons, respectively, (Table, 5).

For L. trifolii, a significant positive correlation with the plant age and the insect population was detected during the two seasons $(r=0.570$ and 0.635 , respectively). While, insignificant positive correlation between both means of maximum \& minimum temperature and the insect population during 2009 and 2010 seasons, $(r=0.462$ and 0.181 and $0.400 \& 0.203)$ (Table, 6$)$.

A significant negative relation was noticed between mean of relative humidity and the above mentioned pests during the two seasons, respectively. For the partial regression analysis, significant positive effect 
was recorded between the above mentioned pest populations and both of maximum and minimum temperature thorough 2009 and 2010 seasons. While, relative humidity had significant negative effect, (Tables, $4,5 \& 6$ ).

Table (5): Effect of plant age and certain climatic factors on the population fluctuation of $T$. tabaci on okra plants at Qalyubiya Governorate.

\begin{tabular}{|c|c|c|c|c|c|c|c|c|c|c|c|}
\hline \multirow{2}{*}{ 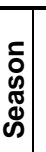 } & \multirow{2}{*}{ Factors } & \multicolumn{3}{|c|}{$\begin{array}{c}\text { Simple correlation } \\
\text { values }\end{array}$} & \multicolumn{4}{|c|}{ Partial regression values } & \multicolumn{2}{|c|}{$\begin{array}{c}\text { Analysis of } \\
\text { variance }\end{array}$} & \multirow{2}{*}{ E.v. \% } \\
\hline & & $\mathbf{r}$ & b & S.E. & b. reg. & S.E. & $\mathbf{T}$ & $\mathbf{P}$ & $\mathbf{F}$ & $\mathbf{P}$ & \\
\hline \multirow{4}{*}{ 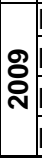 } & Plant age & 0.917 & 0.038 & 0.035 & 9.71 & 0.112 & \begin{tabular}{|l|}
9.332 \\
\end{tabular} & 0.01 & \multirow{4}{*}{27.5} & \multirow{4}{*}{0.01} & \multirow{4}{*}{88.1} \\
\hline & Mean max. temp. & 0.643 & 0.663 & 0.735 & 3.11 & 0.248 & 3.090 & 0.02 & & & \\
\hline & Mean min. temp. & 0.579 & 22.60 & 15.520 & 3.58 & 0.200 & 1.450 & 0.02 & & & \\
\hline & Mean RH\% & -0.738 & 0.003 & 0.144 & -2.99 & 0.153 & 3.262 & 0.03 & & & \\
\hline \multirow{4}{*}{\multicolumn{2}{|c|}{ 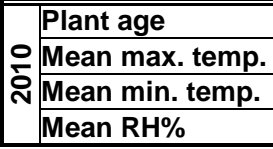 }} & 0.936 & 0.133 & 0.012 & 8.55 & 0.113 & 11.342 & 0.01 & \multirow{4}{*}{32.8} & \multirow{4}{*}{0.01} & \multirow{4}{*}{89.9} \\
\hline & & 0.500 & 0.015 & 0.016 & 4.55 & 0.059 & 4.044 & 0.01 & & & \\
\hline & & 0.542 & 0.543 & 0.289 & 3.59 & 0.117 & 3.187 & 0.02 & & & \\
\hline & & -0.828 & 0.201 & 0.127 & -2.75 & 0.116 & 3.150 & 0.03 & & & \\
\hline
\end{tabular}

r: Simple correlation value. $\quad$ b. reg.: Partial regression coefficient value.

Table (6): Effect of plant age and certain climatic factors on the population fluctuation of $L$. trifolii on okra plants at Qalyubiya Governorate.

\begin{tabular}{|c|c|c|c|c|c|c|c|c|c|c|c|}
\hline \multirow{2}{*}{ 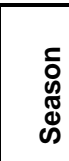 } & \multirow[b]{2}{*}{ Factors } & \multicolumn{3}{|c|}{$\begin{array}{c}\text { Simple correlation } \\
\text { values }\end{array}$} & \multicolumn{4}{|c|}{ Partial regression values } & \multicolumn{2}{|c|}{$\begin{array}{c}\text { Analysis of } \\
\text { variance }\end{array}$} & \multirow{2}{*}{ E.V. \% } \\
\hline & & $r$ & b & S.E. & $\begin{array}{l}\text { b. } \\
\text { reg. }\end{array}$ & S.E. & $\begin{array}{ll}T \\
\end{array}$ & $\mathbf{P}$ & $\mathbf{F}$ & $\mathbf{P}$ & \\
\hline \multirow{4}{*}{2009} & Plant age & 0.57 & 0.04 & 0.04 & 4.81 & 0.11 & 9.33 & 0.01 & \multirow{4}{*}{13.15} & \multirow{4}{*}{0.01} & \multirow{4}{*}{73.4} \\
\hline & $\begin{array}{l}\text { Mean max. } \\
\text { temp. }\end{array}$ & 0.462 & 0.66 & 0.74 & 5.38 & 0.25 & 3.09 & 0.01 & & & \\
\hline & $\begin{array}{l}\text { Mean } \min . \\
\text { temp. }\end{array}$ & 0.181 & 22.60 & 15.52 & 2.49 & 0.20 & 1.45 & 0.02 & & & \\
\hline & Mean RH\% & -0.659 & 0.00 & 0.14 & -5.68 & 0.15 & 3.26 & 0.01 & & & \\
\hline \multirow{4}{*}{2010} & Plant age & 0.635 & 0.13 & 0.01 & 11.27 & 0.11 & 11.34 & 0.01 & \multirow{4}{*}{12.61} & \multirow{4}{*}{0.001} & \multirow{4}{*}{69.2} \\
\hline & $\begin{array}{ll}\text { Mean max. } \\
\text { temp. }\end{array}$ & 0.400 & 0.02 & 0.02 & 7.15 & 0.06 & 4.04 & 0.01 & & & \\
\hline & $\begin{array}{ll}\begin{array}{l}\text { Mean } \\
\text { temp. }\end{array} & \end{array}$ & 0.203 & 0.54 & 0.29 & 2.914 & 0.12 & 3.19 & 0.02 & & & \\
\hline & Mean RH\% & -0.546 & 0.20 & 0.13 & -2.99 & 0.12 & 3.15 & 0.02 & & & \\
\hline
\end{tabular}

The average rate of changes in $L$. trifolii activity due to the changes in the combined effect of the tested factors (plant age, and weather factors), were 73.4 and 69.2 during $1^{\text {st }}$ and $2^{\text {nd }}$ seasons, respectively, (Table, 6). In this regard, Dimetry (1971) in Egypt stated that, the immature stages of Liriomyza congesta was determined mainly by temperature, $20^{\circ} \mathrm{C}$ appeared to be the optimum and at this temperature the maximum numbers of eggs were laid. 
Shalaby (2004) found a significant correlation between minimum temperature and numbers of $L$. trifolii; while insignificant correlation was found between relative humidity and the population of $L$. trifolii.

The simple correlation coefficient " $r$ " indicated that significant positive correlations between $T$. urtica population and both of the plant age $(r=0.913$ and 0.910$)$ and maximum temperature $\left(r=0.716 \& 0.624\right.$ during $1^{\text {st }}$ and $2^{\text {nd }}$ seasons, respectively). While minimum temperature had insignificant positive effect on the population $(r=0.325 \& 0.351$. A significant negative relation was noticed between the daily mean relative humidity and $T$. urtica population, $(r=-0.683 \&-0.789)$ during 2009 and 2010 seasons, respectively. The partial regression analysis for the effect of both maximum and minimum temperature on the $T$. urtica population revealed significant positive effect on both seasons; while, relative humidity had a significant positive effect during 2009, (Table, 7).

The amount of variability, attributed to the combined effect of the tested plant age, and weather factors on $T$. urtica population was 82.10 and 84.70 during 2009 and 2010 seasons, respectively, (Table, 7).

Table (7): Effect of plant age and certain climatic factors on the population fluctuation of T.urticae on okra Qalyubiya Governorate.

\begin{tabular}{|c|c|c|c|c|c|c|c|c|c|c|c|}
\hline \multirow[t]{2}{*}{ Season } & \multirow[t]{2}{*}{ Factors } & \multicolumn{3}{|c|}{$\begin{array}{c}\text { Simple correlation } \\
\text { values }\end{array}$} & \multicolumn{4}{|c|}{ Partial regression values } & \multicolumn{2}{|c|}{$\begin{array}{c}\text { Analysis of } \\
\text { variance }\end{array}$} & \multirow[t]{2}{*}{ E.V. \% } \\
\hline & & $r$ & b & S.E. & b. reg. & S.E. & $\mathbf{T}$ & $\mathbf{P}$ & $\mathbf{F}$ & $\mathbf{P}$ & \\
\hline \multirow{4}{*}{2009} & Plant age & 0.913 & 0.18 & 0.03 & 8.35 & 0.15 & 5.64 & 0.01 & \multirow{4}{*}{17.53} & \multirow{4}{*}{0.01} & \multirow{4}{*}{$82 . .1$} \\
\hline & $\begin{array}{l}\text { Mean max. } \\
\text { temp. }\end{array}$ & 0.716 & 0.73 & 0.68 & 3.54 & 0.33 & 2.08 & 0.02 & & & \\
\hline & $\begin{array}{l}\text { Mean } \\
\text { temp. }\end{array}$ & 0.325 & 12.19 & 14.35 & 14.35 & 0.22 & 2.85 & 0.01 & & & \\
\hline & Mean RH\% & -0.683 & 0.76 & 0.13 & 4.51 & 0.12 & 3.57 & 0.02 & & & \\
\hline \multirow{4}{*}{2010} & Plant age & 0.910 & 0.99 & 0.27 & 4.51 & 0.21 & 4.18 & 0.02 & \multirow{4}{*}{20.93} & \multirow{4}{*}{0.01} & \multirow{4}{*}{84.7} \\
\hline & $\begin{array}{ll}\text { Mean max. } \\
\text { temp. }\end{array}$ & 0.351 & -0.11 & 0.84 & 5.97 & 0.11 & 0.14 & 0.01 & & & \\
\hline & $\begin{array}{l}\text { Mean } \\
\text { temp. }\end{array}$ & 0.624 & -0.19 & 0.68 & 1.40 & 0.21 & 0.28 & 0.01 & & & \\
\hline & Mean RH\% & -0.789 & 0.69 & 0.30 & 4.90 & 0.21 & 2.32 & 0.02 & & & \\
\hline
\end{tabular}

r: Simple correlation value. $\quad$ b. reg.: Partial regression coefficient value.

\section{Efficacy of some pesticides in reducing the population density of some} sap-sucking pests on okra plants:

Data concerning the various tested compounds; Neemazal 5\% EC, Clove oil, $5 \%$ EC, Damaseia 1\% DC and Vertimec 1.8\% EC to evaluate their efficacy against the individuals of $T$. tabaci (nymphs + adults), B. tabaci (egg + nymphal stages), L. trifolii larvae and $T$. urticae (egg + immature stages+adults) infesting okra plants during the two seasons 2009 \&2010 are shown in tables (8\&9).

It is interest to notice that all tested compounds reached its maximum activety after three days of treatment then decreased gradually after 7 days post treatment. Data in table (8) showed that Vertimec exhibited the highest reduction percentages of whitefly, thrips, leafminer and $T$. urticae, during the 
two seasons. Whereas, it eradicated (88.13\&84.65\%), (78.68\&80.60\%), $(72.83 \& 72.28 \%)$ and $(87.95 \& 85.14 \%)$ in population of the above mentioned pests at the same trend.

Table(8): Effect of various treatments against some pestes infesting okra plants at Qalyubiya Governorate during 2009 season.

\begin{tabular}{|c|c|c|c|c|c|c|c|c|}
\hline \multirow[b]{2}{*}{$\begin{array}{c}\mathscr{n} \\
\dot{d} \\
\alpha\end{array}$} & \multirow[b]{2}{*}{$\begin{array}{c}\text { Tested } \\
\text { compounds }\end{array}$} & \multirow[b]{2}{*}{$\begin{array}{c}\text { Pre- } \\
\text { count/leaf }\end{array}$} & \multirow[b]{2}{*}{$\begin{array}{l}\text { I.K. after } \\
\text { one day }\end{array}$} & \multicolumn{3}{|c|}{ \% Reduction after } & \multirow{2}{*}{$\begin{array}{c}\% \\
\begin{array}{c}\% \\
\text { Residual } \\
\text { effect }\end{array}\end{array}$} & \multirow{2}{*}{$\begin{array}{c}\text { General } \\
\text { reduction } \\
\%\end{array}$} \\
\hline & & & & 3 days & 7 days & 10 days & & \\
\hline \multirow{6}{*}{$\begin{array}{l}\bar{d} \\
\mathbb{Z} \\
\text { I্ } \\
\dot{\infty}\end{array}$} & Control & 77.60 & & & & & & \\
\hline & Cloves oil & \multirow{5}{*}{69.40} & $70.05 \mathrm{c}$ & $96.30 \mathrm{a}$ & $84.70 \mathrm{a}$ & $77.50 \mathrm{a}$ & $86.17 \mathrm{a}$ & $82.14 \mathrm{~b}$ \\
\hline & Damaseia & & $86.80 \mathrm{a}$ & $90.00 \mathrm{ab}$ & $80.30 \mathrm{~b}$ & $75.20 \mathrm{bc}$ & $81.83 \mathrm{~b}$ & $83.08 \mathrm{~b}$ \\
\hline & $\begin{array}{l}\text { Neemazal } \\
5 \% \text { EC }\end{array}$ & & $76.00 \mathrm{~b}$ & $78.00 \mathrm{~b}$ & $75.90 \mathrm{c}$ & $72.10 \mathrm{c}$ & $75.33 \mathrm{c}$ & $75.50 \mathrm{c}$ \\
\hline & $\begin{array}{l}\text { Vertimec } \\
1.8 \% E C\end{array}$ & & $90.00 \mathrm{a}$ & $98.00 \mathrm{a}$ & $86.20 \mathrm{a}$ & $78.30 \mathrm{~b}$ & $87.50 \mathrm{a}$ & $88.13 \mathrm{a}$ \\
\hline & LSD & & 3.92 & 14.71 & 3.83 & 3.82 & 2.87 & 2.50 \\
\hline \multirow{6}{*}{$\begin{array}{l}\bar{d} \\
\mathbb{8} \\
\text { I } \\
\text { ト. }\end{array}$} & Control & 21.50 & & & & & & \\
\hline & Cloves oil & \multirow{4}{*}{18.80} & $58.70 \mathrm{~b}$ & $67.70 \mathrm{~b}$ & $51.40 \mathrm{c}$ & $60.30 \mathrm{~b}$ & $59.80 \mathrm{~b}$ & $59.53 \mathrm{~b}$ \\
\hline & Damaseia & & $55.30 \mathrm{~b}$ & $70.10 \mathrm{~b}$ & $61.60 \mathrm{~b}$ & $50.30 \mathrm{~d}$ & $60.67 \mathrm{~b}$ & $59.33 \mathrm{~b}$ \\
\hline & $\begin{array}{l}\text { Neemazal } \\
5 \% \text { EC }\end{array}$ & & $58.70 \mathrm{~b}$ & $67.70 \mathrm{~b}$ & $58.40 \mathrm{~b}$ & $55.30 \mathrm{c}$ & $60.47 \mathrm{~b}$ & $60.03 \mathrm{~b}$ \\
\hline & $\begin{array}{l}\text { Vertimec } 1.8 \\
\% \text { EC }\end{array}$ & & $65.10 \mathrm{a}$ & $90.10 \mathrm{a}$ & $84.40 \mathrm{a}$ & $75.10 \mathrm{a}$ & $83.20 \mathrm{a}$ & $78.68 \mathrm{a}$ \\
\hline & LSD & & 5.15 & 5.77 & 3.94 & 3.98 & 2.73 & 1.91 \\
\hline \multirow{6}{*}{ 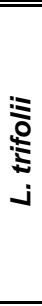 } & Control & 2.10 & & & & & & \\
\hline & Cloves oil & \multirow{5}{*}{1.90} & $50.40 \mathrm{c}$ & $63.20 \mathrm{~b}$ & $51.20 \mathrm{c}$ & $51.20 \mathrm{~b}$ & $55.20 \mathrm{c}$ & $54.00 \mathrm{~b}$ \\
\hline & Damaseia & & $57.10 \mathrm{~b}$ & $62.00 \mathrm{~b}$ & $51.00 \mathrm{c}$ & $48.60 \mathrm{~b}$ & $55.30 \mathrm{c}$ & $55.90 . \mathrm{b}$ \\
\hline & $\begin{array}{l}\text { Neemazal } \\
5 \% \text { EC } \\
\end{array}$ & & $47.10 \mathrm{c}$ & $63.20 \mathrm{~b}$ & $58.90 \mathrm{~b}$ & $51.20 \mathrm{~b}$ & $57.77 \mathrm{~b}$ & $55.10 \mathrm{~b}$ \\
\hline & $\begin{array}{l}\text { Vertimec } 1.8 \\
\% \text { EC }\end{array}$ & & $80.10 \mathrm{a}$ & $78.00 \mathrm{a}$ & $74.30 \mathrm{a}$ & $58.90 \mathrm{a}$ & $70.40 \mathrm{a}$ & $72.83 \mathrm{a}$ \\
\hline & LSD & & 4.15 & 3.29 & 4.20 & 4.41 & 2.36 & 4.70 \\
\hline \multirow{6}{*}{ 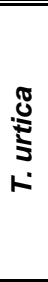 } & Control & 20.15 & & & & & & \\
\hline & Cloves oil & \multirow{5}{*}{31.10} & $58.20 \mathrm{c}$ & $92.50 \mathrm{a}$ & $79.40 \mathrm{c}$ & $74.70 \mathrm{a}$ & $82.20 \mathrm{bc}$ & $76.20 \mathrm{~b}$ \\
\hline & Damaseia & & $67.60 \mathrm{~b}$ & $81.70 \mathrm{~b}$ & $83.80 \mathrm{~b}$ & $77.30 \mathrm{a}$ & $80.93 \mathrm{c}$ & $77.60 \mathrm{~b}$ \\
\hline & \begin{tabular}{|l|} 
Neemazal \\
$5 \%$ EC
\end{tabular} & & $49.30 \mathrm{~b}$ & $90.30 \mathrm{a}$ & $85.30 a b$ & $80.60 \mathrm{a}$ & $85.40 \mathrm{ab}$ & $85.40 \mathrm{a}$ \\
\hline & \begin{tabular}{|l|} 
Vertimec 1.8 \\
$\%$ EC
\end{tabular} & & $93.50 \mathrm{a}$ & $92.60 \mathrm{a}$ & $88.20 \mathrm{a}$ & $77.50 \mathrm{a}$ & $86.10 \mathrm{a}$ & $87.95 \mathrm{a}$ \\
\hline & \begin{tabular}{|l} 
LSD \\
\end{tabular} & & 3.34 & 3.19 & 3.08 & 12.42 & 3.26 & 5.80 \\
\hline
\end{tabular}

The means with the same letters at the same column for each pest are not significantly different at $0.05 \%$ level.

I.K. =Initial Kill

The obtained results showed that, Cloves oil, Damaseia and Neemazal seam to be closely similar in the order of mean reduction percentages of $T$. tabaci, L. trifolii and $T$. urticae (59.53, 59.33 \&60.30), $(54.00,55.90 \& 55.10)$ and $(76.20,77.60 \& 85.40$, respectively) during the season 2009. On the other hand, Cloves oil caused 82.14 and 82.65 mortality 
of eggs and nymphal stages of whitefly followed by Damaseia (83.08\&81.98) and Neemazal (75.50\&73.30) during the two seasons.

Regarding the initial and residual activates, it is clear from tables (8 \& 9) that also Vertimec exhibited the highest initial and residual effect during the two seasons (2009\&2010), while the lowest initial kill was obtained with Cloves oil on whitefly B. tabaci 70.05 and 73.00 at the same trend.

The residual activity could be arranged in descending orders as follows: $87.50>86.17>81.83>75.33$ for Vertimec, Cloves oil, Damaseia and Neemazal on whitefly. While, on T. urticae obtained results were $86.10>$ $85.40>82.20>80.93$ for Vertimec, Neemazal, Cloves oil and Damaseia, respectively. (Tables 8 and 9 ).

The obtained data during 2010 season showed the same trend of initial activity for the tested compounds on whitefly and the two-spider mite, while it is differ on thrips and leafminers. (Table, 9).

Table(9): Effect of various treatments against some pestes infesting okra plants at Qalyubiya Governorate during 2010 season .

\begin{tabular}{|c|c|c|c|c|c|c|c|c|}
\hline \multirow[b]{2}{*}{ Pests } & \multirow[b]{2}{*}{$\begin{array}{l}\text { Tested } \\
\text { compounds }\end{array}$} & \multirow{2}{*}{\begin{tabular}{|c|} 
Pre- \\
count $/$ \\
leaf
\end{tabular}} & \multirow{2}{*}{$\begin{array}{l}\text { I.K. after } \\
\text { one day }\end{array}$} & \multicolumn{3}{|c|}{$\%$ Reduction after } & \multirow{2}{*}{$\begin{array}{c}\% \\
\begin{array}{c}\text { Residual } \\
\text { effect }\end{array}\end{array}$} & \multirow{2}{*}{$\begin{array}{c}\text { General } \\
\text { reduction } \\
\%\end{array}$} \\
\hline & & & & 3 days & 7 days & $\begin{array}{c}10 \\
\text { days }\end{array}$ & & \\
\hline \multirow{6}{*}{ 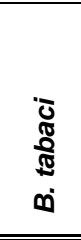 } & Control & 77.60 & & & & & & \\
\hline & Cloves oil & \multirow{4}{*}{69.40} & $73.00 \mathrm{~d}$ & $98.80 \mathrm{a}$ & $89.60 \mathrm{a}$ & $96.30 \mathrm{a}$ & $85.87 \mathrm{a}$ & $82.65 \mathrm{a}$ \\
\hline & Damaseia & & $82.50 \mathrm{~b}$ & $89.10 \mathrm{~b}$ & $80.70 \mathrm{~b}$ & $75.60 \mathrm{~b}$ & $81.80 \mathrm{ab}$ & $81.98 \mathrm{a}$ \\
\hline & Neemazal 5\%EC & & $76.20 \mathrm{c}$ & $76.60 \mathrm{c}$ & $71.70 \mathrm{c}$ & $67.50 \mathrm{c}$ & $71.93 \mathrm{c}$ & $73.00 \mathrm{~b}$ \\
\hline & Vertimec $1.8 \%$ EC & & $90.50 \mathrm{a}$ & $90.60 \mathrm{~b}$ & $86.60 \mathrm{ab}$ & $78.80 \mathrm{~b}$ & $78.80 \mathrm{~b}$ & $84.65 \mathrm{a}$ \\
\hline & \begin{tabular}{|l} 
LSD \\
\end{tabular} & & 1.53 & 2.55 & 5.99 & 1.65 & 4.55 & 4.24 \\
\hline \multirow{6}{*}{ 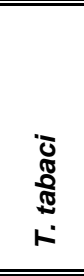 } & Control & 21.50 & & & & & & \\
\hline & Cloves oil & \multirow{5}{*}{18.80} & $56.00 \mathrm{~d}$ & $71.80 \mathrm{~b}$ & $57.50 \mathrm{c}$ & $53.60 \mathrm{a}$ & $60.97 \mathrm{~b}$ & $59.73 \mathrm{~b}$ \\
\hline & Damaseia & & $82.50 \mathrm{a}$ & $89.10 \mathrm{a}$ & $80.70 \mathrm{~b}$ & $75.60 \mathrm{a}$ & $81.80 a b$ & $81.98 \mathrm{a}$ \\
\hline & Neemazal 5\%EC & & & $65.80 \mathrm{c}$ & & $55.50 \mathrm{a}$ & $60.23 \mathrm{~b}$ & $60.17 \mathrm{~b}$ \\
\hline & $\begin{array}{|lll|}\text { Vertimec } & 1.8 \% \\
\text { EC } & & \%\end{array}$ & & $69.20 \mathrm{~b}$ & $91.90 \mathrm{a}$ & $84.50 \mathrm{a}$ & $76.80 \mathrm{a}$ & $84.40 \mathrm{a}$ & $80.60 \mathrm{a}$ \\
\hline & \begin{tabular}{|r|} 
LSD \\
\end{tabular} & & 2.58 & 3.84 & 3.05 & 29.40 & 3.65 & 3.36 \\
\hline \multirow{6}{*}{ 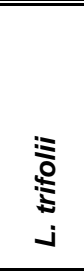 } & Control & 2.10 & & & & & & \\
\hline & Cloves oil & \multirow{5}{*}{1.90} & $57.90 \mathrm{~b}$ & $68.40 \mathrm{~b}$ & $58.90 \mathrm{~b}$ & $51.50 \mathrm{~b}$ & $59.60 \mathrm{~b}$ & $59.18 \mathrm{~b}$ \\
\hline & Damaseia & & $51.50 \mathrm{c}$ & $68.50 \mathrm{~b}$ & $52.00 \mathrm{c}$ & $48.50 \mathrm{~b}$ & $56.33 \mathrm{c}$ & $55.13 \mathrm{c}$ \\
\hline & Neemazal 5\%EC & & $48.30 \mathrm{~d}$ & $52.70 \mathrm{c}$ & $48.00 \mathrm{~d}$ & $48.50 \mathrm{~b}$ & $49.73 d$ & $49.38 \mathrm{~d}$ \\
\hline & \begin{tabular}{|lr} 
Vertimec & 1.8 \\
$\%$ \%E & \\
\end{tabular} & & $83.80 \mathrm{a}$ & $71.60 \mathrm{a}$ & $67.10 \mathrm{a}$ & $66.60 \mathrm{a}$ & $68.43 \mathrm{a}$ & $72.28 \mathrm{a}$ \\
\hline & LSD & & 2.90 & 2.63 & 1.85 & 3.02 & 2.47 & 2.94 \\
\hline \multirow{6}{*}{$\begin{array}{l}\stackrel{8}{S} \\
\stackrel{5}{5} \\
\text { r }\end{array}$} & & 20.15 & & & & & & \\
\hline & Cloves oil & \multirow{4}{*}{31.10} & $50.00 \mathrm{c}$ & $91.40 \mathrm{a}$ & $79.80 \mathrm{~b}$ & $77.40 \mathrm{~b}$ & $82.87 \mathrm{~b}$ & $74.65 \mathrm{~b}$ \\
\hline & Damaseia & & $66.90 \mathrm{~b}$ & $80.50 \mathrm{~b}$ & $80.80 \mathrm{~b}$ & $74.00 \mathrm{~b}$ & $78.43 \mathrm{c}$ & $75.55 \mathrm{~b}$ \\
\hline & Neemazal 5\%EC & & $45.70 \mathrm{~d}$ & $90.30 \mathrm{a}$ & $82.90 \mathrm{ab}$ & $81.90 \mathrm{a}$ & $85.03 \mathrm{a}$ & $75.20 \mathrm{~b}$ \\
\hline & $\begin{array}{|lr|}\begin{array}{l}\text { Vertimec } \\
\% E C\end{array} & 1.8 \\
\end{array}$ & & $85.90 \mathrm{a}$ & $90.30 \mathrm{~b}$ & $86.90 \mathrm{a}$ & $77.40 \mathrm{~b}$ & $84.87 \mathrm{ab}$ & $85.13 b$ \\
\hline & & & & & & & & \\
\hline
\end{tabular}

The means with the same letters at the same column for each pest are not significantly different at $0.05 \%$ level.

I.K. =Initial Kill 
Effects of applied treatments on chlorophyll content in okra leaves:

By analyzing the chlorophyll $A$ content in leaves of okra plant after spraying with Neemazal 5\% EC, Clove oil, 5\% EC, Damaseia 1\% DC and Vertimec $1.8 \% \mathrm{EC}$, data in table (10) revealed that, there were no significant different in chlorophyll of the treated leaves with Clove oil and Neemazal as the corresponding amounts of chlorophyll A were 47.80 and $47.00 \mathrm{mg} / 100 \mathrm{gm}$ fresh wt., while the plants which kept free from any aplications had the lowest content $(43.20 \mathrm{mg} / 100 \mathrm{gm}$ fresh wt.) in 2009 season. Also, there was a significant difference between the chlorophyll $A$ content in leaves of the treated okra plants during 2010 season, as the leaves sprayed with Cloves oil hade the highest amount $(50.60 \mathrm{mg} / 100 \mathrm{gm}$ fresh wt.) followed by those treated with Damaseia and Neemazal when compared with the leaves obtained from the control plots. Regarding chlorophyll A content in plants sprayed with Vertimec, they showed significantly lower chlorophyll A content than that of the control.

Table (10): Effect of spraying of some compounds on chlorophyll A content in leaves of okra plants ( $\mathrm{mg} / 100 \mathrm{gm}$ fresh wt.) during 2009 and 1010 seasons.

\begin{tabular}{|l|c|c|}
\hline \multicolumn{1}{|c|}{ Season } & 2009 & 2010 \\
\hline Treatments & $47.80 \mathrm{a}$ & $50.60 \mathrm{a}$ \\
\hline Plant Extract damaseia & $45.30 \mathrm{ab}$ & $45.10 \mathrm{~b}$ \\
\hline Neemazal 5\%EC & $47.00 \mathrm{a}$ & $46.70 \mathrm{~b}$ \\
\hline Vertimec 1.8\%EC & $45.30 \mathrm{ab}$ & $42.70 \mathrm{c}$ \\
\hline Control & $43.20 \mathrm{~b}$ & $46.30 \mathrm{~b}$ \\
\hline L.S.D. & 3.42 & 1.76 \\
\hline
\end{tabular}

\section{REFERENCES}

Abou-Zaid, M.M. (2003): Studies on some mites associated with some vegetable crops. M.Sc Thesis, Fac. of Sci., Al-Azhar Unive. 180pp.

Basma, M.A.; H.H. Shalaby and N.F. Arafat (2006): The toxic effect of some plant extracts and ortus against Tetranychus urticae Koch and Euseius scutalis Athias-Henroit. Sci. j. Fac. Sci. Minoufiya Unive. 10: 1-14.

Dimetry, N.Z. (1971): Biological studies on a leaf mining Diptera, Liriomyza trifolii (Burgess) attacking beans. Bull. Sco. Entomol. Egypt, 55: 55-69.

Eid,S.M. (1985): Note on the natural variability for some qualitative and quantitative characters in Okra (Abelmoschus esculentus( L.) Moench). Ind. J. Agr. Sci. 42(5): 437.

El-Kawass, H.M.L. (2000): Ecological and biological studies on some mites associated with orchards and field crops. M.Sc. Thesis, Fac. Of Agric., El-Azhar Univ. 146pp. 
El-Lakwah, F.A.; M.M. Azab and M.K.W. Ebrahim (2003): Effect of modified atmospheres on mortality of some stored product insects and tjier effect alone and in mixtures with some insecticides on seed of certain crops. Romanian Conf., 513-529.

Gameel, O.I. (1973): Field evaluation of insecticides for jassid, Empoasca lybica De Berg and whitefly, Bemisia tabaci (Genn.) control on cotton. Bull. Entomo. Soc. Egypt, Econo. Ser., 7: 113-122.

Henderson, C.F. and W.A. Tilton (1955): Test with acaricides against the wheat mite. J. Econ. Ent. 49: 157-161.

Jaydeb G.; S.K. Ghosh; H. Chatterjee and S.K. Senapati (1999): Pest constraints of okra under Terai region of West Bengal. Indian, J. Ento. 61(4): 362-371

Kappoor, C.V.; M. Poul; K. Tyotika and T. Kapus (1997): Seasonal incidence of mite species infesting Okra (Hibiscus esclentus) and brinjal (Solanum melongena) in Punjab. Indian J. of Agric. Sci., 67(8): 325329.

Kumar, V. and D.D. Sharma (1993): Bio-Ecology and chemical control of spider mite, Tetranychus ludeni Zecher on okra. Indian J. of Plant Protec. 21 (1): 68-71.

Lentern Van, J.C. and L.P. Noldus (1984): Whitefly- plant relationship: Behavioural and ecological aspect. In (whiteflies: their Bionomcs, pest status and management.) (Gerling, D. Ed.) Published intercept Ltd., 348.

Park, Y.L. and J.H. Lee (2007): Seasonal dynamics of economic injury levels for Tetranychus urticae Koch (Acari, Tetranychidae) on Cucumis sativus L. J. Appl. Entomo. 131(8): 588-592.

Perkins, H.H. (1983): Identification and processing of honeydew contaminated cotton. Textile Research J. 53-55.

Shalaby, S.H. (2004): Studies on the efficiency of some new pest control measures against certain pests of common bean. Ph.D. Thesis, Fac. Agric.Moshtohor, Zagazig Univ., 265pp.

SAS Institute (1988): SAS / Stat user's guide, 6.03 ed. SAS institute, Cary, NC. 


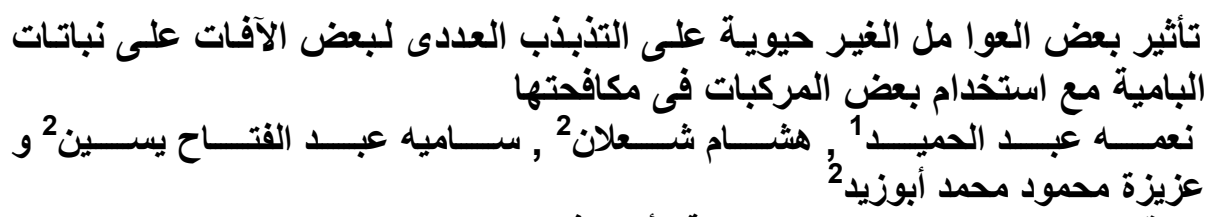

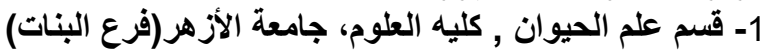

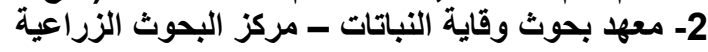

أجريت تجربة حقلية في محافظة القليو بيه خلال موسمين متتاليين 2009, 2010 لدراسة الئا

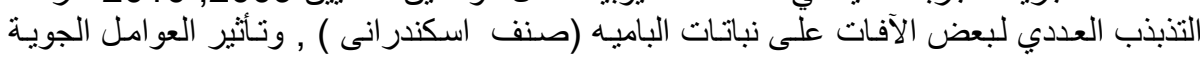

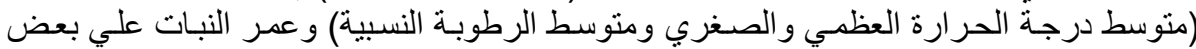

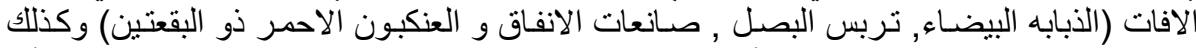

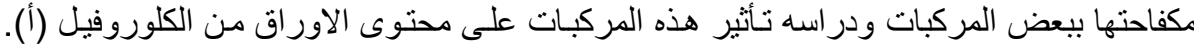

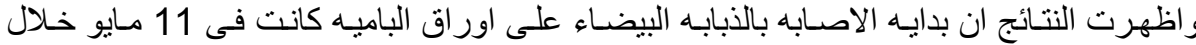

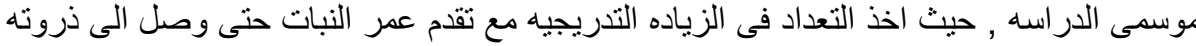

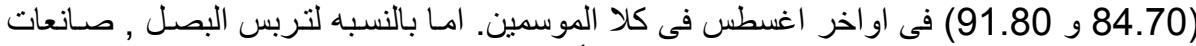

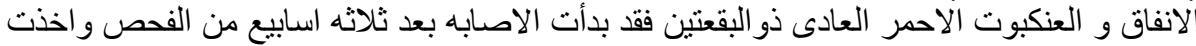

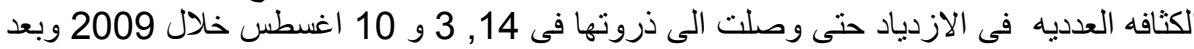

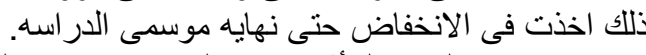

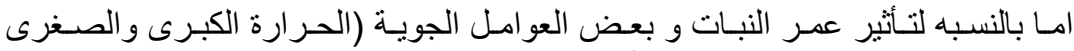

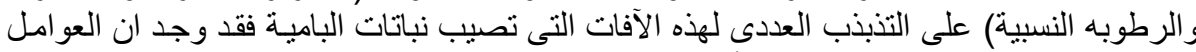

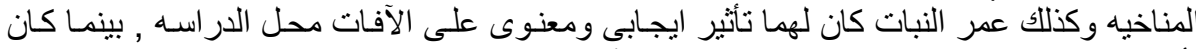

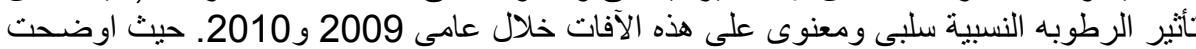

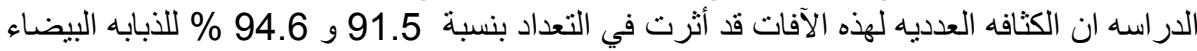

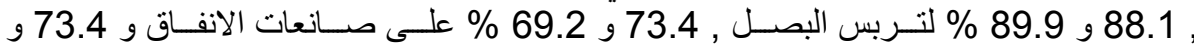
69.2\% للعنكبوت الاحمر ذو البقعتين للموسمين 2009 و 2010 و 2010 على الترتيب.

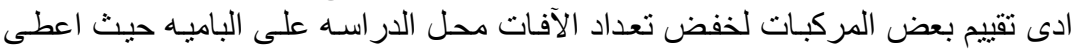
Vertimec

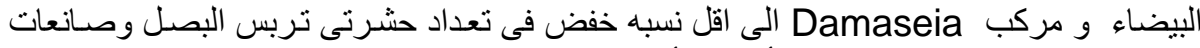

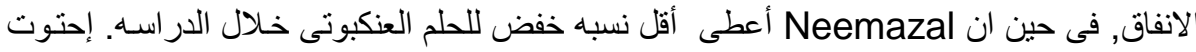

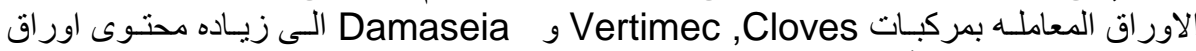

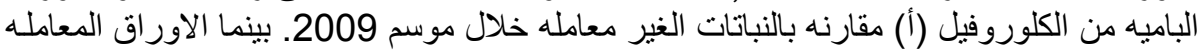

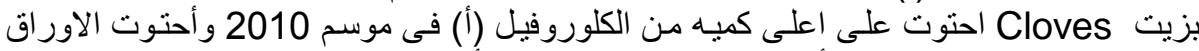
المعامله بمركب Vertimec أقل محتوى من الكلوروفيل (أ) مقارنه بالنباتات الغير معامله.

كلية الزراعة - جامعة المنصورة مركز البحوث الزراعية
قام بتحكيم البحث

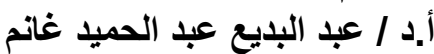
أ.د / الد اعن على طله 